Egyptian Journal of Aquatic Biology \& Fisheries

Zoology Department, Faculty of Science,

Ain Shams University, Cairo, Egypt.

ISSN $1110-6131$

Vol. 24 (7): 171- 182 (2020)

www.ejabf.journals.ekb.eg

\title{
Feeding Habits and Reproduction Period of Sepia officinalis (Linnaeus, 1758) Captured from East Mediterranean Sea
}

\author{
Salah M. Aly ${ }^{1,4 *}$, Ashraf Y. El-Dakar ${ }^{2}$, Attia A. O. El-Aiatt ${ }^{3}$ and Ahmed M. AL-Beak $^{4,5}$ \\ ${ }^{1}$ Department of Pathology, College of Vet. Medicine, Suez Canal University, Ismailia, Egypt. \\ ${ }^{2}$ Faculty of Aquaculture and Fisheries, Arish University, Al-Arish branch, Egypt. \\ ${ }^{3}$ National Institute of Oceanography and Fisheries (NIOF), Al-Arish branch, Egypt. \\ ${ }^{4}$ General Authority for Fish Resources Development (GAFRD), Al-Arish branch, Egypt. \\ ${ }^{5}$ Fish Farming and Technology Institute, Suez Canal University, Ismailia, Egypt.
}

"Corresponding author: salahaly@ hotmail.com

\begin{tabular}{|l|}
\hline ARTICLE INFO \\
Article History: \\
Received: Aug. 23, 2020 \\
Accepted: Oct. 12, 2020 \\
Online: Oct. 20, 2020 \\
\hline Keywords: \\
Sepia officinalis, \\
Feeding habits, \\
Reproductive cycle, \\
Sex ratio, \\
Mediterranean Sea. \\
\end{tabular}

\section{INTRODUCTION}

Recently, the marine resources and ecosystems of the East Mediterranean Sea subjected to increasing pressure, which driven by not only demographic and economic growth but also by diversification, as well as the intensification of marine and maritime activities. Fishing along the Mediterranean Sea has a special concern from its countries, in which several methods of exploitation of this resource have developed therefrom the earliest times. Common cuttlefish (Sepia officinalis) distribute in a wide range of water temperate. They inhabited from South Norway and North Atlantic Ocean to Mauritanian and Senegal coasts, also from Eastern Atlantic waters distributed to the East Mediterranean Sea throughout the Aegean Sea, Black Sea, Adriatic Sea and the Marmara Sea (FAO, 2016).
This study aimed to investigate some biological aspects of Common cuttlefish (Sepia officinalis) as feeding habits and the reproductive cycle in the East Mediterranean Sea. Stomach fullness index (FUI), relative importance index (IRI\%), sex ratio, gonado-somatic index, and the reproductive cycle were investigated among $590 \mathrm{~S}$. officinalis samples from September 2016 to August 2017 where $55.76 \%$ of gutted empty stomachs (FUI 0) and $11.53 \%$ were full stomachs (FUI 4). The study revealed that fishes, crustaceans, and cephalopods were the most preferred prey by males and females. The overall sex ratio record was dominated by males during the year but females were dominant in November and March. Male's gonads activity starts to reproduce in winter and spring while female's gonads activity starts to reproduce in autumn and winter. Data analyzed at the present work conclude that $S$. officinalis is multi-feeding mollusks that consume a wide range of prey taxa also, its reproductive cycle extends for at least 6 months. 
In the eastern Mediterranean Sea, the biological cycle of Common cuttlefish includes seasonal migration from the deep sea to inshore waters and vice versa. It appears in this region at trammel net catches in the late summer and the beginning of autumn (between September and October) then, it last to the late spring (between April and May). However, it may appear in trawl catch with small amounts between July and August. Similar to many other cephalopod species, S. officinalis biological and ecological characteristic's as well as its stock assessment, have been unsatisfactorily studied in the East Mediterranean Sea.

The diet of $S$. officinalis includes crustaceans, bony fishes, mollusks, polychaetes and nemertean worms (Nixon, 1987; Castro and Guerra, 1990; Pinczon du Sel et al., 2000). Studying of food and feeding habits of marine aquatic animals based on the analysis of stomach content has become an important ecological and biological factors stated to describe the life history of fishes like growth, maturation, reproduction, spawning, and migratory movements.

The spawning period of this species extends throughout the year in the Western Mediterranean, that peaks in spring and summer (Mangold-Wirz, 1963). In the northern and central Adriatic Sea, it reproduces in April and May, but females with mature eggs can found in June and July (Manfrin Piccinetti and Giovanardi, 1984).

The major objective of this research is to study the biology and habits of the common cuttlefish ( $S$. officinalis) as food, feeding, and reproduction during its life cycle in the East Mediterranean Sea.

\section{MATERIAL AND METHODS}

\section{Sampling and measurements}

During two fishing season from September 2016 to August 2017, a total of 590 Common cuttlefish (S. officinalis) samples were taken from North Sinai local market. Fish were cleaned, sorted and measured by dorsal mantle length (DML) in cm, total weight (TW) in gram, and sex identified for males and females, gonads extracted and weighted nearest to 0.01 gram.

\section{Data analysis}

\section{Feeding habits}

Stomach was removed, weighted and classified its contents monthly, the stomach fullness index (FUI) was stated using a particular scale from 0 to 4: (FUI 0) - empty, (FUI 1) - 25\% of its volume, (FUI 2) - from $25 \%$ to $50 \%$ of its volume, (FUI 3) - from $50 \%$ to $75 \%$ of its volume, (FUI 4 ) - full (Castro and Guerra, 1990). Extracted preys were classified to the lowest possible taxon level. Digested preys beyond visual recognition were classed as undetermined preys. The quantitative and qualitative analysis were used to describe the relative importance of each prey according to MendesAlves et al., (2006), where the index of relative importance (IRI\%) was used (Hyslop, 1980), taking into account the number of prey items and their frequency of occurrence (Borme et al., 2013).

The following parameters were measured to determine the feeding biology of S. officinalis as:

- Percent frequency of occurrence $(\mathrm{F} \%)=$ (number of stomachs containing prey item i / total number of non-empty stomachs) x 100 . 
- Percentage by number $(\mathrm{Cn} \%)=$ (number of individuals of prey item $\mathrm{i} /$ total number of all prey items) x 100 .

- Percentage by weight $(\mathrm{Cp} \%)=($ weight of prey item $\mathrm{i} /$ total weight of all prey items $) \mathrm{x} 100$.

- The analyzing of food items was recognized using the relative importance index (IRI) of (Pinkas et al., 1971) by the following equation: $\mathrm{IRI}=(\mathrm{Cn}+\mathrm{Cp}) \times \mathrm{F}$.

- The relative importance Common cuttlefish index was again converted to $\%$ of the total IRI as IRI \% = ( IRI/ $\Sigma$ IRI $) \times 100$.

- Feeding Coefficient (Q) (Hureau, 1970), which characterizes the relative importance of the different preys in a diet. Using this coefficient, preys were separated into three categories $(\mathrm{Q}>200=$ principal prey $),(20<\mathrm{Q}<200=$ secondary prey $),(\mathrm{Q}<20=$ accessory prey).

\section{Reproduction biology}

- The numeric proportions of sexes were expressed as male and female percentages also as a male: female ratio, then were compared with a balanced sex-ratio (1:1) with a $\chi^{2}$ test.

- Sexed and the stage of sexual maturity determined according to the scale adopted by Scarcella et al., (2002) as I immature, II maturing, III mature, and IV fully mature.

- For seasonal considerations, months were grouped as follows: spring - April to June, summer - July to September, autumn - October to December, winter, January to March.

- The reproductive period was determined by analyzing the monthly variation in the gonad maturity stages as well as the gonado-somatic index, it is represented as:

\section{GSI $=\mathbf{G W} / \mathbf{E W} \times \mathbf{x} 100$.}

Where GW: the gonad weight and EW: the total tissue weight (or body).

\section{Statistical analysis}

Analysis of variance (ANOVA) between sexes was calculated to separate feeding differences according to the sex. The correlation between gonado-somatic index (GSI) and the temperature was tested using the Spearman rank correlation coefficient ( $\rho$ or $r_{s}$ ) (Zar, 2010).

\section{RESULTS AND DISCUSSIONS}

\section{Feeding habits}

- Stomach fullness index

The analysis of $590 \mathrm{~S}$. officinalis stomach for both sexes males and females revealed 329 samples were empty (FUI 0) that presents $55.76 \%, 17.46 \%$ were $25 \%$ (FUI 1), $13.05 \%$ were $50 \%$ (FUI 2), $2.20 \%$ were $75 \%$ (FUI 3) and $11.53 \%$ were $100 \%$ (FUI 4). The seasonal variation between sexes showed that, in autumn females tend to feed more than males; for females (FUI $0=49 \%$ and FUI $4=18 \%$ ) and males (FUI $0=55 \%$ and FUI $4=8 \%$ ). While, in spring males tend to feed more than females; for males (FUI $0=50 \%$ and FUI $4=20 \%$ ) and females (FUI $0=74 \%$ and FUI $4=2 \%$ ), 
unsexed S. officinalis found in summer and its stomach index was (FUI $0=51 \%$ and FUI $4=5 \%$ ) (Figurs 1-3).

Numerous empty stomachs of Common cuttlefish during this study reveal its feeding habits. Feeding intensity generally is depending on food abundance, feeding behavior during the day, and seasonal variation. Consequently, present results of (FUI) are affected with a) the low biological productivity of the Mediterranean Sea which it is one of the lowest observed in the global ocean (Powley et al., 2017), b) cuttlefish active at night but catch process continuous during the day, $c$ ) feeding intensity affected with a seasonal variation on ingestion and digestion, additionally females was noticed diminish feeding over the season of reproduction at the present study, and $d$ ) The fullness index related to gear type; cuttlefish caught by trawling are more suitable for diet analysis than those caught by static gear, one explanation could be related to the time set for the traps and nets, sometimes lasting two or three days (Bettoso et al., 2016).

Results of males and females feeding habits indicated that, they share the same prey items and no significant differences were found between sexes. These results agree with Castro and Guerra, (1990); and Mzaki et al., (2017) who also reported no significant differences between sexes concerning the feeding habit.

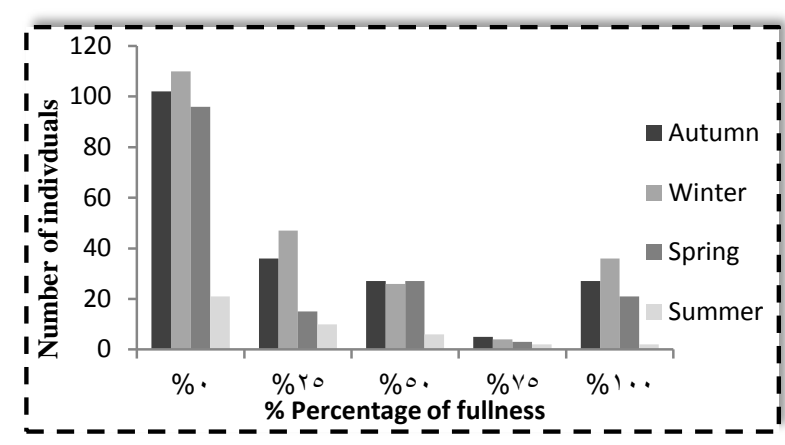

Fig 1. Percentage of $S$. officinalis stomach fullness for $S$. officinalis during different seasons.

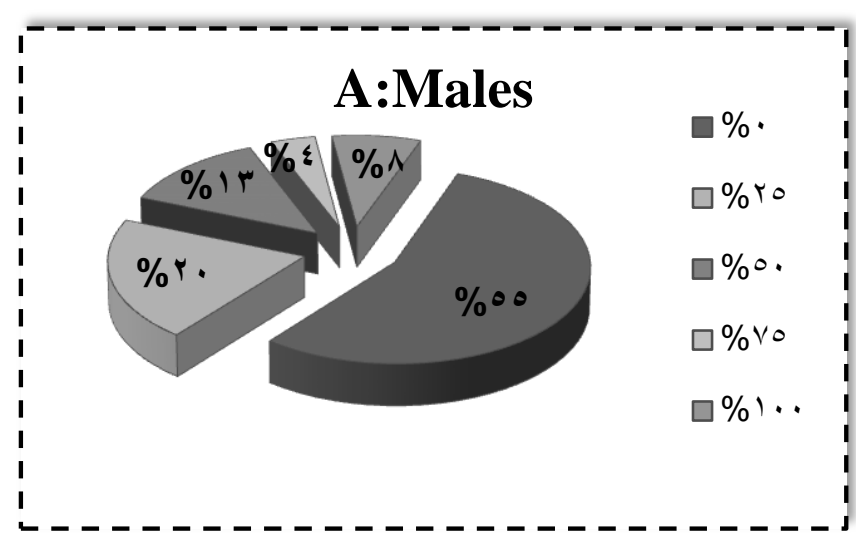

Fig 2. Stomach fullness index (FUI) males and females.

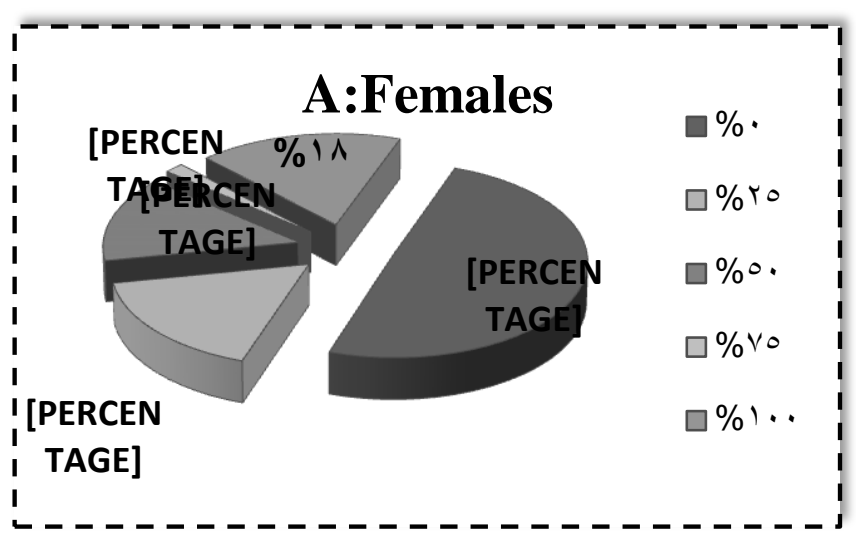




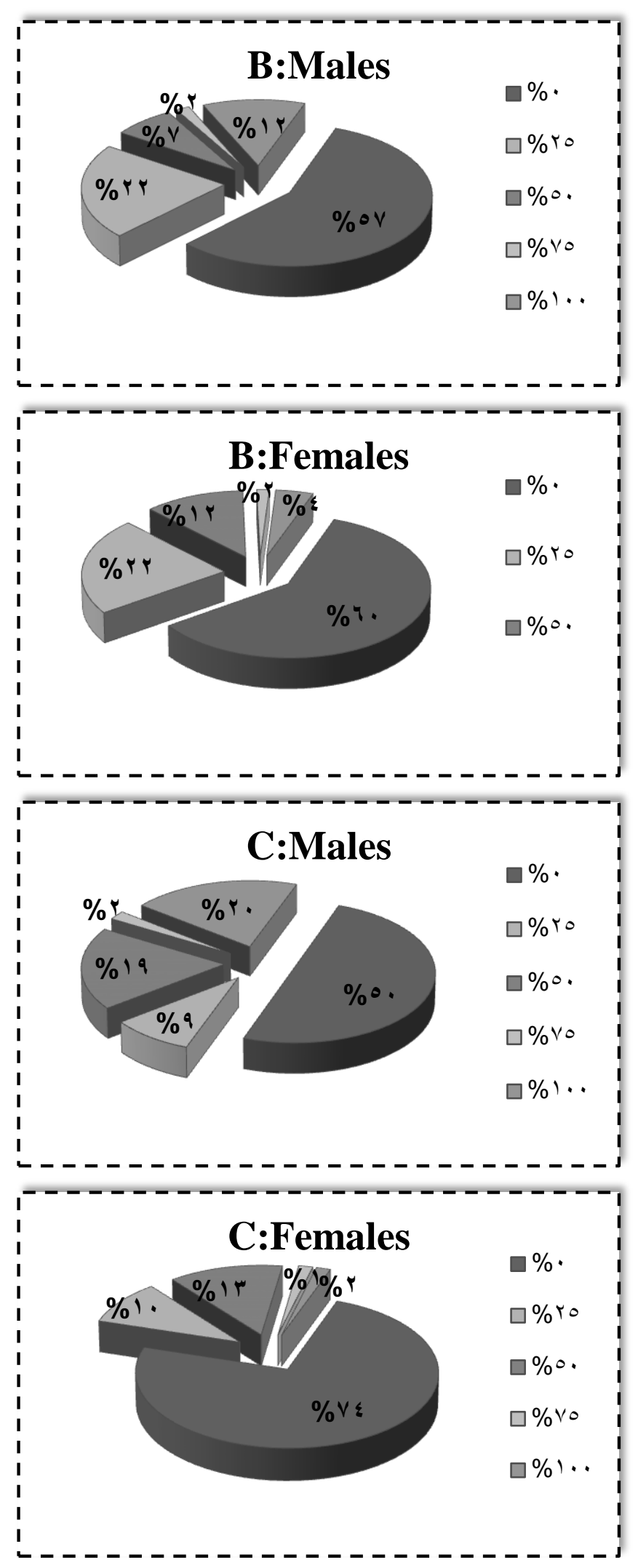




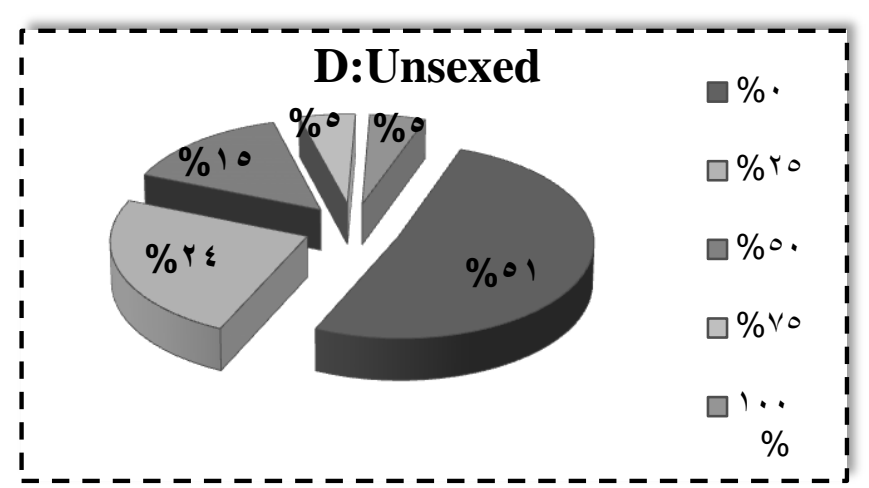

Fig 3. Differences between males, females, and unsexed $S$. officinalis stomach fullness index (FUI) during $\{A\}$ autumn, $\{B\}$ winter, $\{C\}$ spring, and $\{D\}$ summer.

\section{- Quantitative and qualitative analysis of stomach contents}

Analysis of Common cuttlefish stomach contents classified it as multi-feeding mollusks that consume more than 19 species and prey taxa (Table 1). Fishes are the most appearance prey within stomach content followed by crustaceans, cephalopods, bivalves and cnidarian (Coelenterata). The relative important index (IRI\%) for males is slightly different than females which prefer fishes in its feeding habits (IRI\% 54.14 for males and 51.53 for females) also females favor crustaceans than males (IRI\% 46.79 for females and 41.05 for males), cephalopods prey are preferred by males (IRI\% 4.2 for males and 1.28 for females). No statistical differences between sex on frequency of occurrence (ANOVA, $\mathrm{p}>0.05, \mathrm{~F}=0.00081, \mathrm{~F}$ crit= 4.96).

Results of Quantitative and qualitative analysis of stomach contents declared no significant difference in feeding habits between males and females, as previously reported by many authors in the Atlantic Ocean and the Adriatic Sea (Castro and Guerra, 1990; Pinczon du Sel and Daguzan, 1997; Guerra, 2006; Mendes-Alves et al., 2006, and Bettoso et al., 2016). Conversely, a significant change in the diet occurred with growth. In this way, seasonal differences could be linked primarily to cuttlefish size and reproduction (Mendes-Alves et al., 2006).

\section{Reproduction biology}

- Sex ratio

The overall sex ratio of $590 \mathrm{~S}$. officinalis samples used during this analysis was 322 males to 228 females that conform 1.41:1. The other 40 samples were unsexed. Analysis of chi-square with degrees of freedom $(\mathrm{k}-1=1) \chi^{2}=16.065$ but $\chi^{2} 0.05,1=3.841$ that means there are statistically difference when $\chi^{2}>\chi^{2} 0.05,1$, therefore, reject $\mathrm{H}_{\circ}$ and accept HA which the sample data came from a population not having 1:1 ratio of Male: Female (Table 2). The monthly overall sex ratio was higher for males in October, December, January, and February. But it was higher for females in November and March, then it was equal for both in September and April. The sex ratio of males was higher than females by 3.67:1, 1.21:1, 2:1 and 1.50:1 in October, December, January, and February, respectively. The sex ratio of females was higher than males by $0.54: 1$ and $0.50: 1$ in November and March, $\left(\chi^{2}=0\right.$, $0.581,1.333$ and 0 also $\left.\chi^{2} 0.05,1=3.841\right)$ which reflects no statistically different when $\chi^{2}<\chi^{2} 0.05,1$, therefore, accept $\mathrm{H}_{\circ}$ and reject $\mathrm{HA}$ which the sample data came from a population having 1:1 ratio of 
Male: Female for months September, December, March, and April, respectively. Analysis of chisquare was $\chi^{2}=27.429,9.481,18.667$ and 4 but $\chi^{2} 0.05,1=3.841$ that means there are statistical difference when $\chi^{2}>\chi^{2} 0.05,1$, therefore, reject $\mathrm{H}_{\circ}$ and accept HA for months October, November, January, and February, respectively (Table 2).

Table 1. Feeding habits of S. officinalis males and females by 19 main prey categories.

\begin{tabular}{|c|c|c|c|c|c|c|c|c|c|c|}
\hline \multirow{2}{*}{ Category } & \multicolumn{5}{|c|}{ Males } & \multicolumn{5}{|c|}{ Females } \\
\hline & F\% & $\mathrm{Cn} \%$ & Ср\% & IRI\% & $\mathbf{Q}$ & F\% & $\mathrm{Cn} \%$ & Сp\% & IRI\% & $\mathbf{Q}$ \\
\hline Algae & 0.766 & 0.383 & 0.766 & 0.040 & 0.294 & 0.766 & 1.149 & 1.533 & 0.075 & 1.762 \\
\hline Cnidarian & 1.149 & 0.575 & 3.065 & 0.191 & 1.762 & 4.598 & 1.533 & 2.299 & 0.645 & 3.523 \\
\hline Bivalves & 1.533 & 0.958 & 4.598 & 0.388 & 4.404 & 4.215 & 1.724 & 3.831 & 0.857 & 6.606 \\
\hline Cephalopods & $\begin{array}{c}11.49 \\
4\end{array}$ & 8.429 & 9.195 & 4.200 & 77.509 & 4.981 & 6.705 & 7.663 & 1.279 & 51.379 \\
\hline Crustaceans & $\begin{array}{c}42.52 \\
9\end{array}$ & $\begin{array}{c}31.22 \\
6\end{array}$ & $\begin{array}{c}15.32 \\
6\end{array}$ & $\begin{array}{c}41.04 \\
5\end{array}$ & 478.560 & $\begin{array}{c}54.02 \\
3\end{array}$ & $\begin{array}{c}30.07 \\
7\end{array}$ & $\begin{array}{c}18.39 \\
1\end{array}$ & $\begin{array}{c}46.78 \\
7\end{array}$ & $\begin{array}{c}553.13 \\
3\end{array}$ \\
\hline Penaeus japonicus & $\begin{array}{c}12.26 \\
1\end{array}$ & 6.130 & $\begin{array}{c}38.31 \\
4\end{array}$ & $\begin{array}{c}11.29 \\
7\end{array}$ & 234.876 & $\begin{array}{c}13.79 \\
3\end{array}$ & 5.747 & $\begin{array}{c}36.01 \\
5\end{array}$ & $\begin{array}{c}10.29 \\
3\end{array}$ & $\begin{array}{c}206.98 \\
5\end{array}$ \\
\hline Metapenaeus stebbingi & $\begin{array}{c}11.87 \\
7\end{array}$ & 5.939 & $\begin{array}{c}34.48 \\
3\end{array}$ & 9.953 & 204.783 & $\begin{array}{c}13.02 \\
7\end{array}$ & 5.556 & $\begin{array}{c}32.18 \\
4\end{array}$ & 8.785 & $\begin{array}{c}178.79 \\
9\end{array}$ \\
\hline Metapenaeus monoceros & $\begin{array}{c}11.87 \\
7\end{array}$ & 5.939 & $\begin{array}{c}39.08 \\
0\end{array}$ & $\begin{array}{c}11.08 \\
6\end{array}$ & 232.087 & $\begin{array}{c}12.26 \\
1\end{array}$ & 5.939 & $\begin{array}{c}40.61 \\
3\end{array}$ & $\begin{array}{c}10.19 \\
9\end{array}$ & $\begin{array}{c}241.18 \\
8\end{array}$ \\
\hline Penaeus semisulcatus & $\begin{array}{c}12.64 \\
4\end{array}$ & 6.322 & $\begin{array}{c}37.54 \\
8\end{array}$ & $\begin{array}{c}11.49 \\
9\end{array}$ & 237.372 & $\begin{array}{c}13.41 \\
0\end{array}$ & 6.322 & $\begin{array}{c}39.08 \\
0\end{array}$ & $\begin{array}{c}10.87 \\
9\end{array}$ & $\begin{array}{c}247.06 \\
0\end{array}$ \\
\hline Portunidae & $\begin{array}{c}13.79 \\
3\end{array}$ & 6.897 & $\begin{array}{c}45.97 \\
7\end{array}$ & $\begin{array}{c}15.12 \\
0\end{array}$ & 317.083 & $\begin{array}{c}14.55 \\
9\end{array}$ & 6.513 & $\begin{array}{c}43.67 \\
8\end{array}$ & $\begin{array}{c}13.05 \\
8\end{array}$ & $\begin{array}{c}284.49 \\
4\end{array}$ \\
\hline Fishes & $\begin{array}{c}67.81 \\
6\end{array}$ & $\begin{array}{c}58.42 \\
9\end{array}$ & $\begin{array}{c}18.39 \\
1\end{array}$ & $\begin{array}{c}54.13 \\
7\end{array}$ & $\begin{array}{c}1074.55 \\
9\end{array}$ & $\begin{array}{c}54.02 \\
3\end{array}$ & $\begin{array}{c}58.81 \\
2\end{array}$ & $\begin{array}{c}16.85 \\
8\end{array}$ & $\begin{array}{c}51.52 \\
8\end{array}$ & $\begin{array}{c}991.47 \\
1\end{array}$ \\
\hline Atherina hepsetus & $\begin{array}{c}21.45 \\
6\end{array}$ & $\begin{array}{c}10.72 \\
8\end{array}$ & $\begin{array}{c}17.62 \\
5\end{array}$ & 6.322 & 189.075 & $\begin{array}{c}18.77 \\
4\end{array}$ & $\begin{array}{c}10.15 \\
3\end{array}$ & $\begin{array}{c}15.32 \\
6\end{array}$ & 6.029 & $\begin{array}{c}155.60 \\
5\end{array}$ \\
\hline Pomadasys stridens & $\begin{array}{c}11.87 \\
7\end{array}$ & 5.939 & $\begin{array}{c}35.24 \\
9\end{array}$ & 5.084 & 209.333 & $\begin{array}{c}11.11 \\
1\end{array}$ & 5.747 & $\begin{array}{c}32.18 \\
4\end{array}$ & 5.312 & $\begin{array}{c}184.96 \\
5\end{array}$ \\
\hline Argyro & 6.897 & 3.448 & $\begin{array}{c}33.71 \\
6\end{array}$ & 2.663 & 116.264 & 5.747 & 3.831 & $\begin{array}{c}37.54 \\
8\end{array}$ & 2.998 & $\begin{array}{c}143.86 \\
2\end{array}$ \\
\hline Saurida & 7.280 & 3.640 & $\begin{array}{c}26.05 \\
4\end{array}$ & 2.246 & 94.831 & 6.513 & 4.023 & $\begin{array}{c}29.11 \\
9\end{array}$ & 2.721 & $\begin{array}{c}117.14 \\
4\end{array}$ \\
\hline Pomatom & $\begin{array}{c}13.79 \\
3\end{array}$ & 6.897 & $\begin{array}{c}37.54 \\
8\end{array}$ & 6.370 & 258.951 & $\begin{array}{c}11.87 \\
7\end{array}$ & 7.280 & $\begin{array}{c}34.48 \\
3\end{array}$ & 6.252 & $\begin{array}{c}251.02 \\
4\end{array}$ \\
\hline$S$ & 7.280 & 3.640 & $\begin{array}{c}46.74 \\
3\end{array}$ & 3.811 & 170.138 & 8.429 & 3.257 & $\begin{array}{c}43.67 \\
8\end{array}$ & 4.987 & $\begin{array}{c}142.24 \\
7\end{array}$ \\
\hline Mug & 7.663 & 3.831 & $\begin{array}{c}42.14 \\
6\end{array}$ & 3.661 & 161.477 & 6.897 & 4.215 & $\begin{array}{c}39.08 \\
0\end{array}$ & 3.764 & $\begin{array}{c}164.70 \\
7\end{array}$ \\
\hline Platycephalidae & $\begin{array}{c}14.94 \\
3\end{array}$ & 7.471 & $\begin{array}{c}26.05 \\
4\end{array}$ & 5.206 & 194.654 & $\begin{array}{c}11.49 \\
4\end{array}$ & 5.939 & $\begin{array}{c}23.75 \\
5\end{array}$ & 4.302 & $\begin{array}{c}141.07 \\
3\end{array}$ \\
\hline $\mathrm{S}_{1}$ & 3.448 & 1.724 & $\begin{array}{c}12.26 \\
1\end{array}$ & 0.501 & 21.139 & 4.598 & 2.682 & $\begin{array}{c}14.55 \\
9\end{array}$ & 0.999 & 39.048 \\
\hline $\begin{array}{l}\text { Undetermined fish } \\
\text { species }\end{array}$ & $\begin{array}{c}22.22 \\
2\end{array}$ & $\begin{array}{c}11.11 \\
1\end{array}$ & $\begin{array}{c}32.18 \\
4\end{array}$ & 9.998 & 357.599 & $\begin{array}{c}18.77 \\
4\end{array}$ & $\begin{array}{c}11.68 \\
6\end{array}$ & $\begin{array}{c}35.24 \\
9\end{array}$ & $\begin{array}{c}11.10 \\
7\end{array}$ & $\begin{array}{c}411.91 \\
4\end{array}$ \\
\hline
\end{tabular}

*(F\%)Percent frequency of occurrence, $(\mathrm{Cn} \%)$ percentage by number, $(\mathrm{Cp} \%)$ percentage by weight, (Q)feeding Coefficient, and (IRI\%) percent of relative importance index. 
The overall sex ratio of $S$. officinalis showed that females appear in a significant number higher than males in reproductive seasons. Present results on East Mediterranean are identical in (male/female) sex ratio with Jardas et al., (2001) who was in favor of males along the eastern Adriatic coast. Differently, females dominated over males, as noted by Guerra and Castro, (1988) and Bettoso et al., (2016). Additionally, sex ratio recorded a well-balance by Guerra and Castro, (1988) in set net fishery, whereas trawling caught more females on the other hand males dominated in the traps, accordingly, they suggest that the sex ratio can also be related to the season and the size of specimens.

Table 2. Sex ratio of S. officinalis males and females captured from the East Mediterranean Sea.

\begin{tabular}{cccccc}
\hline \multirow{2}{*}{ Month } & \multicolumn{5}{c}{ Sex ratio } \\
\cline { 2 - 5 } & $\mathbf{N}=\mathbf{5 5 0}$ & Males & Females & Sex ratio & $\chi^{\mathbf{2}}$ \\
\hline September & 8 & 4 & 4 & 1.00 & 0.000 \\
October & 84 & 66 & 18 & 3.67 & 27.429 \\
November & 108 & 38 & 70 & 0.54 & 9.481 \\
December & 62 & 34 & 28 & 1.21 & 0.581 \\
January & 168 & 112 & 56 & 2.00 & 18.667 \\
February & 100 & 60 & 40 & 1.50 & 4.000 \\
March & 12 & 4 & 8 & 0.50 & 1.333 \\
April & 8 & 4 & 4 & 1.00 & 0.000 \\
\hline
\end{tabular}

\section{- Maturity evolution}

During all maturity stages, average gonads weights of $S$. officinalis females were heavier than males (Av. ovaries weights $17.65 \mathrm{gm}$, Av. tests weights $2.14 \mathrm{gm}$ ). Maturity seasonal variation was observed for both sex, gonads differentiation starts in early growth stages; it begins for females in autumn moreover it begin for males at winter (Table 3). Ripe males appear in spring (stage IV $80.95 \%$ ) also ripe females appear in winter (stage III and IV, 51.43 and 20\%). Between all 590 samples captured from East Mediterranean Sea 550 samples were males and females that represent 93.22\% from all samples, while, 40 individuals were unsexed that represent $6.78 \%$ from all samples which caught in summer season.

As previously observed, maturation evolution in the East Mediterranean Sea of S. officinalis may attain sexual maturity at different sizes, the males being more precocious than the females. This result is similar to that observed by Mangold-Wirz (1963) in the Western Mediterranean; (Guerra and Castro, 1988) in the Ria de Vigo, and Bettoso et al. (2016) in the Northern Adriatic Sea. 
Table 3. Sexual maturity stages of S. officinalis males and females according to seasons, captured from East Mediterranean Sea.

\begin{tabular}{ccccccc}
\hline Season & Gender & \% I* & \% II & \% III & \% IV & Total no. \\
\hline \multirow{2}{*}{ Autumn } & Males & 73.28 & 24.43 & 2.29 & 0.0 & 131 \\
& Females & 67.42 & 21.97 & 9.09 & 1.52 & 132 \\
Winter & Males & 6.59 & 85.63 & 3.59 & 4.19 & 167 \\
& Females & 12.63 & 14.74 & 52.63 & 20.00 & 95 \\
\multirow{2}{*}{ Spring } & Males & 0.0 & 9.52 & 9.52 & 80.95 & 21 \\
Summer & Females & 0.0 & 100 & 0.0 & 0.0 & 4 \\
\hline \multicolumn{2}{c}{ Total numbexed } & 0 & 0 & 0 & 0 & 40 \\
\multicolumn{2}{c}{ Percentage } & 208 & 224 & 73 & 45 & 590 \\
\hline
\end{tabular}

I: immature, II: maturing, III: mature, and IV: fully mature.

\section{- Gonado-Somatic index}

The gonadosomatic index (GSI) of males was generally increased from the size group $7-7.9$ $\mathrm{cm}$ to size group $12-12.9 \mathrm{~cm}$ then it decreased irregularly to the size group $19-19.9 \mathrm{~cm}$. Similarly, for females it increased from size group $7-7.9 \mathrm{~cm}$ to highest value in size group $11-11.9 \mathrm{~cm}$ then it decreased irregularly to the least value in size group $19-19.9 \mathrm{~cm}$. Common cuttlefish has a short life cycle lasting between 1 and 2 years depending on the latitude at which it lives (Domingues $\boldsymbol{e t}$ al., 2006), consequently, an early reproductive cycle that occurs rapidly from the small size of dorsal mantle length $(11-12 \mathrm{~cm})$ for both sex. Monthly gonadosomatic index has fluctuation as it high in September, January, and February for females (GSI values ranged between $0.28 \%$ to $5.92 \%$ for females) also, it is high in December, March, and April for males (GSI values ranged between $0.42 \%$ to $1.47 \%$ for males), consequently, males tests activity starts to reproduce in winter and spring, and females ovaries activity starts to reproduce in autumn and winter (Fig. 4 \& 5). A strong negative correlation between sea surface temperature and mean GSI monthly value ( $\rho=-0.62$ for males, $\rho=$ 0.45 for females) that mean the lower sea surface temperature leads to more ripened cuttlefish and completely gonads maturation.

The relevance between evolution of males and females gonads maturation, and sea surface temperature was proved in the present study. Thus, the reproductive cycle during the present study found to be tack place early than other authors in the northern Mediterranean and the Adriatic Sea. Manfrin Piccinetti and Giovanardi, (1984), in the northern and central Adriatic Sea found the reproduction of S. officinalis occurs in spring-summer, with a peak in April and May. Önsoy and Salman, (2005) reported two peaks in March and June and spawning period of cuttlefish in Homa lagoon from March to June. Güven and Ozbaş, (2007) observed a spawning period extending throughout the year in S. officinalis in the Antalya Bay with spawning peaks (June-July). This shows that the spawning season and the reproductive peaks for the cuttlefish are very variable and probably very closely connected to the environmental conditions. Duysak et al., (2014), mentioned that maturing population was observed in all sampled months for females; stage IV (full matured) was 
observed most of the sampling period except in September, October, and April. The fully mature male population was also observed in all months except in March.

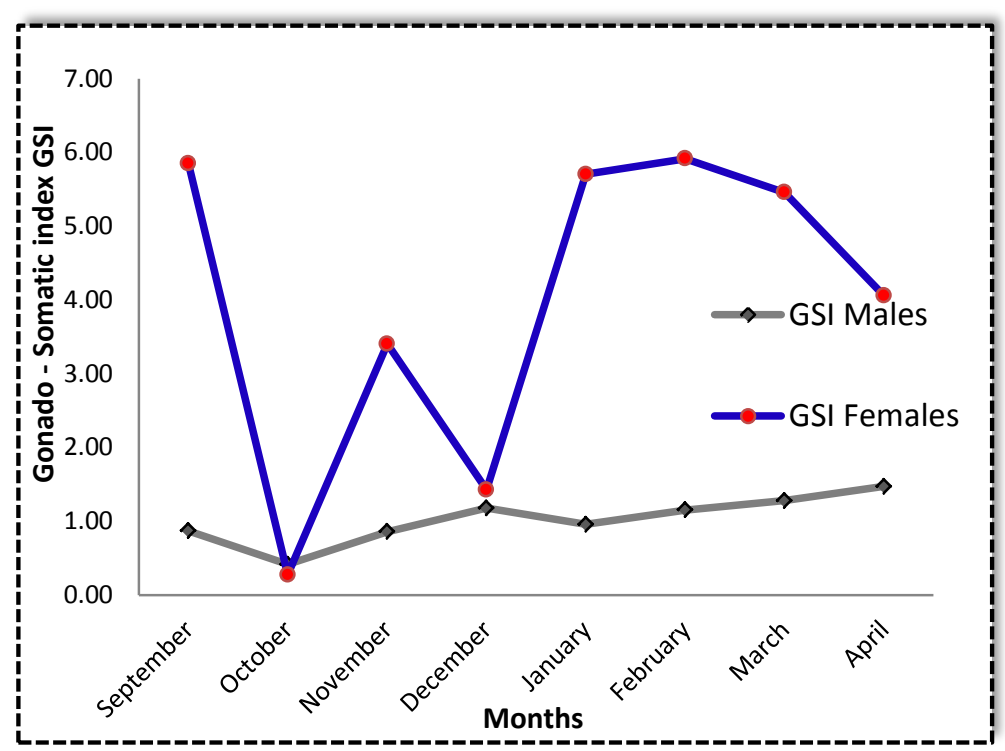

Figure 4. Gonadosomatic index of $S$. officinalis males and females during months.

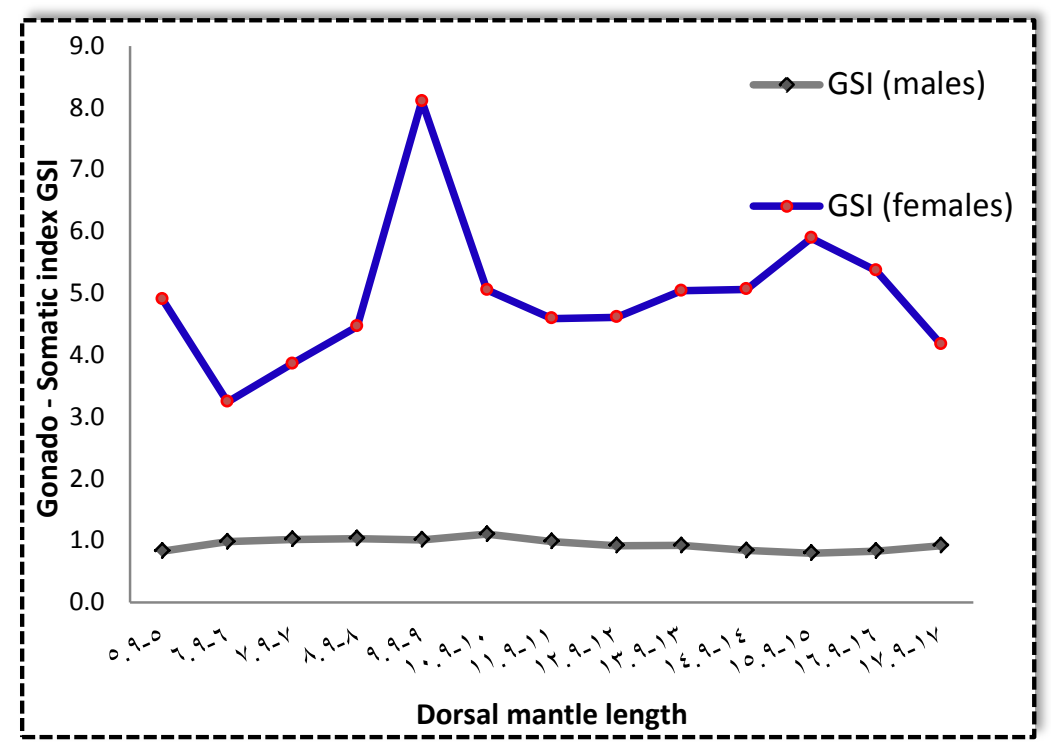

Figure 5. Gonadosomatic index of $S$. officinalis males and females by size group.

\section{CONCLUSION}

Feeding habits and reproduction biology of Common cuttlefish was first studied in the East Mediterranean Sea at the North Sinai coast. Females tend to feed more than males over the year but males tend to feed more than females in spring. Fishes are the most appearance prey within $S$. 
officinalis stomach content followed by crustaceans. The overall sex ratio declares that males were dominated than females over the year but females were dominated in reproductive season.

\section{REFERENCES}

Bettoso, N.; Borme, D.; Faresi, L.; Aleffi, I.; Orlando-Bonaca, M. and Lipej, L. (2016). New insights on the biological parameters of the exploited cuttlefish Sepia officinalis L. (Mollusca: Cephalopoda) in the northern Adriatic Sea in relation to the main fishing gears employed. Mediterranean Marine Science, 17(1): 152-162.

Borme, D.; Tirelli, V. and Palomera, I. (2013). Feeding habits of European pilchard late larvae in a nursery area in the Adriatic Sea. Journal of Sea Research, 78: 8-17.

Castro, B.G. and Guerra, A. (1990). The diet of Sepia officinalis (Linnaeus, 1758) and Sepia elegans (D’Orbigny, 1835) (Cephalopoda, Sepioidea) from the Ría de Vigo (NW Spain). Scientia Marina, 54 (4): 375-388.

Domingues, P. M.; Bettencourt, V. and Guerra, A. (2006). Growth of Sepia officinalis in captivity and in nature. Vie et Milieu - Life \&Environment, 56: 109-120.

Duysak, Ö; Özcan, G; Çek, Ş. and Türeli, C. (2014). Reproductive biology of the common cuttlefish (Sepia officinalis Linnaeus, 1758) in Iskenderun Bay (Northeastern Mediterranean Sea). INDIAN J MAR SCI, 43(9): 6.

FAO (2016). The State of Mediterranean and Black Sea Fisheries 2016. FAO/General Fisheries Commission for the Mediterranean, 145.

Guerra, A. (2006). Ecology of Sepia officinalis. Vie et Milieu - Life \& Environment, 56: 97107.

Güven, O. and Özbaş, M. (2007). Reproduction of common cuttlefish (Sepia officinalis, L., 1758) in Antalya Bay. Rapport Commission International pour l'exploration scientifique de la Mer Mediterranée, Monoco, 38: 494.

Hureau, J. C. (1970). Comparative biology of some Antarctic fish (Nototheniidae). Bulletin of the Institution of Oceanography, Monaco, 68:244 [In French].

Hyslop, E.J., (1980). Stomach contents analysis: a review of methods and their application. Journal of Fish Biology, 17: 411-429.

Jardas, I.; Pallaoro, A.; Cetinić, P. and Dulčić, J. (2001). Cuttlefish, Sepia officinalis L., 1758, in the trammel bottom set catches along the eastern Adriatic coast (Croatia). Rapport Commissione Internationale Mer Méditerranée, 36: 277.

Manfrin Piccinetti, G. and Giovanardi, O. (1984). Données sur la biologie de Sepia officinalis L. dans l'Adriatique obtenues lors de expéditions Pipeta. FAO Fisheries Report, 290: 135-138.

Mangold-Wirz, K. (1963). Biologie des Cephalopodes benthiques et nectoniques de la Mer Catalane. Vie Milieu, 13: 1-285.

Mendes-Alves, D.; Cristo, M.; Sendão, J. and Cerveira Borges, T. (2006). Diet of the cuttlefish Sepia officinalis (Cephalopoda: Sepiidae) off the south coast of Portugal (eastern Algarve). Journal of the Marine Biological Association of the UK, 86: 429-436.

Mzaki, F.; Manchih, K.; Idrissi, H.F.; Boumaaz, A.; Haddouch, A.B. and Tazi, O. (2017). Diet of the common cuttlefish Sepia officinalis (Linnaeus, 1758) (Cephalopoda: Sepiidae) in the Southern Moroccan Atlantic waters, Cap Boujdour, Cap Blanc. AACL Bioflux, 10 (6): 1692-1710. 
Nixon, M. (1987). Cephalopod diets. p. 201-219. In: Cephalopod life cycles II. Comparative reviews. Boyle, P.R. (Ed.). Academic Press, London.

Önsoy, B. and Salman, A. (2005). Reproductive biology of the common cuttlefish Sepia officinalis L. (Sepiida: Cephalopoda) in the Aegean Sea. Turk. J. Vet. Anim. Sci., 29: 613-619.

Pinczon du Sel, G.; Blanc, A. and Daguzan, J. (2000). The diet of the cuttlefish Sepia officinalis L. (Mollusca: Cephalopoda) during its life cycle in the northern Bay of Biscay (France). Aquatic Sciences, 61:167-178.

Pinczon du Sel, G.P. and Daguzan, J. (1997). A note on sex ratio, Sepia officinalis length and diet of a population of cuttlefish L. (Mollusca: Cephalopoda) sampled by three fishing methods. Fisheries Research 32: 191-195

Powley, H. R., Cappellen, P. V., \& Krom, M. D. (2017). Nutrient cycling in the Mediterranean Sea: the key to understanding how the unique marine ecosystem functions and responds to anthropogenic pressures. Mediterranean Identities-Environment, Society, Culture. InTech, 47-77.

Scarcella G.; Fabi, G.; Grati, F. and Lucchetti, A. (2002). Fattori che influenzano l'ingresso di Sepia officinalis L. 1758 nelle trappole. Biologia Marina Mediterranea, 9 (1): 161-169.

Zar, J.H. (2010). Biostatistical Analysis. 5th Edition. Pearson Prentice-Hall, Upper Saddle River, NJ, 944. 